\title{
The Influence of the Work Environment, Financial Rewards, and Type a Personality on the Choice of a Public Accountant Career
}

\author{
Faneshia Tangke Rerung1*, David Adechandra Ashedica Pesudo²
}

1,2 Universitas Kristen Satya Waacana, , Salatiga, Indonesia

\section{ART ICLE INFO}

Article history:

Received July 19, 202

Revised July 20, 2021

Accepted August 10, 2021

Available online August 25, 2021

Keywords:

Work Environment, Financial Rewards, Type A Personality

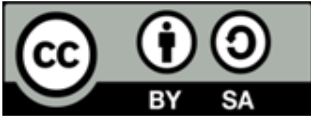

This is an open access article under the CC BY-SA license.

Copyright $(2021$ by Author. Published by Universitas Pendidikan Ganesha.

\begin{abstract}
A B S T R A C T
The influence of work environment, financial rewards and personality type $\mathrm{A}$ on the choice of a public accountant career. This research aims to determine the effect of the work environment, financial rewards, and type A personality on the choice of a public accountant career. The subjects of this study were accounting students, Universitas Kristen Satya Wacana class of 2017 and 2018. This study used a quantitative approach with a linear regression testing method. The sample of this study was 182 respondents. 79 respondents obtained the distribution of data acquisition from the 2017 class and 103 respondents from the 2018 batch. The data was obtained by distributing questionnaires through the google form. Based on the t-test, it can be concluded that the work environment has a positive effect on the choice of a public accountant career, financial rewards have no effect on the choice of a public accountant career, and type A personality has a positive effect on the choice of a public accountant career. Based on the research that has been done, the following conclusions are obtained. First, the work environment has a positive effect on the choice of a public accountant career. Second, financial rewards do not influence the choice of a public accountant career. Students prefer to have various experiences first, so they do not consider the number of financial rewards obtained. Third, type A personality has a positive effect on the choice of a public accountant career.
\end{abstract}

\section{INTRODUCTION}

Public Accountant is an accountant who has obtained permission from the Minister of Finance to provide services in the form of attestation and non-attestation services (Asri et al., 2020; Murdiawati, 2020). The said attestation services include; audit services on prospective financial statements; audit services on pro forma financial information reporting; review services on financial statements; and other attestation services stated in the Standar Profesi Akuntan Publik (SPAP) (Chan, 2012; Lukman \& Juniati, 2017). The Public Accountant profession is a promising profession with bright job prospects because this profession provides an invaluable learning experience and intellectual challenges (Wicaksono dan Aisyah, 2017). In Indonesia, the interest of students of the Accounting Study Program in choosing the profession of Public Accountant is categorized as very low. According to data from the World Bank, an average of 35,000 people graduates in Accounting from various universities in a year, Indonesia is 35,000 people, higher than Thailand's 20,000, the Philippines 15,000, Malaysia 5000 (Murdiawati, 2020). Based on World Bank data, Indonesia ranks first in accounting graduates compared to ASEAN countries. However, IAPI stated that as of 2019, the number of Public Accountants in Indonesia was only 1,416. This number is very low compared to the number of graduates of accounting students in Indonesia in a year. From this explanation, it can also be seen that the Public Accountant profession in Indonesia is still very small and not enough to meet the growing needs of companies to be audited (Suyono, 2014; Yendrawati, 2017). There has not been a balance between the need and availability of auditors in Indonesia. The number of companies that must be audited is increasing daily, while the number of auditors in Indonesia is still very low.

The choice of the profession should start while still in college because this can be the first step for accounting students to choose their profession according to their wishes and abilities. Planning a career from scratch can spur a person in planning education, skills, and skills that can support his future career achievement (Fauziah, 2020; Lukman \& Juniati, 2017). There are four professions in the accounting field, a career in Public Accountants, corporate accountants, accounting educators, and finally, a career as a 
government accountant (Rahayu \& Putra, 2019; Ramdani \& Zulaikha, 2014). Graduates from colleges majoring in accounting can determine their careers in various accounting fields according to their expertise or branch of accounting science. To become a Public Accountant, a person must pass a bachelor's degree in accounting and pass the Public Accountant certification exam organized by the Indonesian Institute of Accountants (IAI) and work professionally by the code of ethics for Public Accountants (Suharti, S. \& Irman, 2020; Suyono, 2014).

The low interest of accounting students to choose a career as a Public Accountant can be influenced by several factors (Suharti, S. \& Irman, 2020). Factors that can influence a person's interest in a career in the field of Public Accountants are financial rewards, professional training, professional recognition, social scores, work environment, and labour market considerations. The work environment is a work atmosphere that includes work (routine, often over time, and attractive). Work pressure and the level of competition exist in the work environment. A Public Accountant must have a strong character and commitment to deal with various situations in the work environment. Previous research stated that work environment factors could influence accounting students in choosing a career as a Public Accountant (Suyono, 2014). It is because the reward or satisfaction that will be obtained is greater than the sacrifice faced. Another study stated that the work environment does not affect students' interest in becoming a Public Accountant (Laksmi \& Al Hafis, 2019). The reason is that students do not have work experience as Public Accountant.

The financial award factor is a factor that is very considered in determining a person's job or career because the purpose of a person's work is to get an award or salary. A financial award or salary is a form of appreciation that someone obtains after completing the responsibilities they have. In this case, the responsibility is the job description given (Merdekawati dan Sulistyawati, 2011). A high starting salary, work bonuses, pension funds, overtime pay, and potential salary increases are all components of financial rewards. The financial reward factor affects the interest of accounting students in choosing a career to become a Public Accountant (Laksmi \& Al Hafis, 2019). It is because financial rewards are the main attraction for students to choose a career in Public Accountants (Suyono, 2014). The financial award factor has a significant effect on students in choosing a career as a Public Accountant. Accounting students at the beginning of work expect financial rewards or a high starting salary and are long-term.

Personality factors influence accounting students in choosing a career as a Public Accountant. Personality is a psychological characteristic of every person that shows or reflects how a person responds to the environment in any situation (Chan, 2012). Personality type can influence a person's orientation towards achievement, actions against risks faced, choices, reactions when under pressure, ways of communicating, and self-resistance (Wicaksono dan Aisyah, 2017). There are two personality types, type A and type B personality (Matthews, 1982). Someone who has a type A personality is more competitive, achievement-oriented, feels the time is always pressing, does not like to relax, and is always impatient and angry when faced with delays or delays. People who are deemed incompetent. In contrast to someone with a type B personality, he is always relaxed, has no guilt, works without looking at his lust, does not rush, which can cause impatience and irritability. The Public Accountant profession is expected to be responsible for the work given and work with time pressure, which people with type A personalities own. In contrast, type B personality is less responsible and difficult to work with time pressure. From this explanation, it can be concluded that type B personality is not suitable for a Public Accountant. Type A personality has better performance than students with type B personality (Sari, 2019). A person with type A personality, completes work on time or less than the allotted time (Iswati, 2017). The characteristics of a person with type A personality who completes work quickly pays more attention to quantity than quality of work that can be completed, when making decisions, tends to look at experiences from the past, compared to considering other alternatives, which are considered time-consuming. Type B personality is the opposite of type A (Iswati, 2017). From the phenomena that have been explained, it can be concluded that students who have personality type A are more likely to choose a career as a Public Accountant. A Public Accountant must have professional ethics, including professional behavior, professional responsibility, technical standards, public interest, integrity, confidentiality, objectivity, competence, and professional care.

The public accountant's environment will always change depending on the type and characteristics of the client or company to be audited. Everyone has a different personality from one another. Professionalism is one of the main requirements for a Public Accountant to provide guarantees to clients. Public Accountants must also have the commitment, integrity, high spirit, and optimism of accountants in responding to unexpected circumstances. At the beginning of March 2020, Indonesia was hit by an outbreak of the Corona Virus Disease-19 (Covid-19) which until now it is not certain when the virus will end (Coman et al., 2020; Susil et al., 2020). The Covid-19 virus outbreak has caused enormous impacts in various sectors, one of which is Public Accountants. The increasing number of cases has resulted in the government issuing a PSSB (Large-Scale Social Restrictions) policy that requires all work to be done from home to break the chain of the spread of Covid-19. This PSBB policy greatly impacts several fields of work, including the career 
of a Public Accountant, resulting in the audit process being carried out remotely. The auditor must maintain audit quality and obtain sufficient and appropriate audit evidence to support the audit opinion. However, the implementation of this PSBB greatly affects the results in obtaining audit evidence due to restrictions on access and travel and personal availability from auditors and auditees. Indirectly, the auditor is required to make relevant changes, such as exploring alternative audit procedures, including the use of technology. As a consequence, the auditor must delay the issuance of the audit report.

There have been several previous studies that discussed this topic. Still, the difference in this study lies in the addition of the Type A personality variable which is considered to influence students' interest in a career as a Public Accountant. This research was conducted on students at Universitas Kristen Satya Wacana (FEB UKSW). FEB UKSW cooperates with campus affiliate IAI to provide facilities in CA (Chartered Accountant) and CPA (Certified Public Accountant) exams. It can lead students to have a career in Public Accountants and demand that the Accounting Study Program graduates are more competent and qualified. Therefore, this study aims to determine the effect of the work environment, financial rewards, and type A personality on choosing a Public Accountant career during a pandemic. This research can provide theoretical benefits that can provide an overview of student perceptions to choose a career as a Public Accountant and being a reference for further research for academics and input for relevant agencies to make a policy that can attract accounting students to have a career as a Public Accountant.

\section{METHODS}

This research was conducted at the Fakultas Ekonomika dan Bisnis (FEB) Universitas Kristen Satya Wacana Salatiga. The object of research is students of the Faculty of Economics and Business accounting study program. The population in this study refers to the 2017 and 2018 FEB UKSW students who are still active in the accounting study program. The reason for choosing students from the 2017 and 2018 batches is because they have studied at FEB UKSW for at least one year, so they already have the goal of having a career in the field they want after studying at UKSW. In addition, the reason for choosing the 2017 and 2018 batches is because students have taken auditing courses. Auditing courses are knowledge that an accountant must possess, which will later be applied to the Public Accountant profession. According to data and information from the FEB UKSW, the number of students from the 2017 and 2018 accounting study programs who are still active is 333 students. From all active students, this research will be sampled using the purposive sampling method. The selection of purposive sampling is because the sampling is by predetermined criteria so that the data obtained is more accurate. This sample selection aims to take a random sample with calculations using the Slovin formula.

This study uses a quantitative approach (Sugiyono, 2014). A quantitative approach is used to test the hypothesis by analyzing the influence of the work environment, financial rewards, and personality type A in choosing a Public Accountant career. The type of data used in this study is primary data carried out through questionnaires distributed via google form by distributing links to accounting students at Universitas Kristen Satya Wacana in the form of written questions about the factors mentioned above in choosing a career that an accountant will pursue. The questionnaire will be measured using an ordinal scale with one (1) to four (4), with a choice of a scale of one (1) for the answer choices Strongly Disagree (STS) to a scale of four (4) for the answer choices Strongly Agree (SS). The aim is to ensure that respondents agree or disagree with each answer and avoid extreme data during the data collection and processing process. The research model used is multiple linear regression, and then the data obtained will be processed using SPSS. The variables, operational definition of variables, and empirical indicators is presented in Table 1.

Table 2. Empirical Variables and Indicators

\begin{tabular}{|c|c|c|}
\hline Variable & Operational Definition & Empirical Indicator \\
\hline $\begin{array}{c}\text { Public Accountant } \\
\text { Career }\end{array}$ & $\begin{array}{l}\text { Public Accountants are professional } \\
\text { accountants who sell their services to the } \\
\text { public, especially in the field of auditing } \\
\text { financial statements made by their } \\
\text { clients (Mulyadi, 2012) }\end{array}$ & 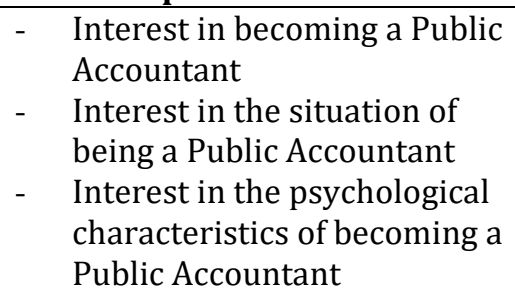 \\
\hline Work environment & $\begin{array}{l}\text { The work environment is an atmosphere } \\
\text { or various things that exist around } \\
\text { workers physically, and non-physically } \\
\text { that can affect a person's work } \\
\text { (Febriyanti, 2019). }\end{array}$ & $\begin{array}{ll}\text { - } & \text { Routine work } \\
\text { - } & \text { Attractive or many challenges } \\
\text { - } & \text { Frequent overtime } \\
\text { - } & \text { Pressure at work }\end{array}$ \\
\hline
\end{tabular}




\begin{tabular}{|c|c|c|}
\hline Variable & Operational Definition & Empirical Indicator \\
\hline & & $\begin{array}{ll}\text { - } & \text { Competition among } \\
\text { employees is high } \\
\text { - } & \text { Comfortable work } \\
\text { environment }\end{array}$ \\
\hline Financial Awards & $\begin{array}{l}\text { A financial award is an award in the form } \\
\text { of financial. Financial rewards or salaries } \\
\text { can be considered in career selection } \\
\text { because the main purpose of a person } \\
\text { working is to get an award or salary } \\
\text { (Wicaksono \& Aisyah, 2017). }\end{array}$ & $\begin{array}{ll}- & \text { High starting salary } \\
- & \text { Pension fund } \\
- & \text { Work bonuses } \\
- & \text { Potential salary increase } \\
& \text { Overtime pay }\end{array}$ \\
\hline Type A Personality & $\begin{array}{l}\text { Type A personality is an individual } \\
\text { personality who is very competitive and } \\
\text { achievement-oriented, feels the time is } \\
\text { always pressing, does not like to relax } \\
\text { and is impatient, and gets angry easily } \\
\text { when faced with delays or someone who } \\
\text { is considered incompetent (Matthews, } \\
\text { 1982). }\end{array}$ & $\begin{array}{ll}- & \text { Competitive } \\
\text { - } & \text { Impatient } \\
\text { - } & \text { Haste } \\
\text { - } & \text { Ambitious } \\
\text { - } & \text { Responsible } \\
\text { - } & \text { Hard worker }\end{array}$ \\
\hline
\end{tabular}

Analysis of the data used in this study using Multiple Linear Regression analysis. Before performing multiple linear regression analysis, the validity and reliability of the research questionnaire used will be tested. Then, the classical assumption test consisted of normality, heteroscedasticity, and multicollinearity tests (Ghozali, 2014). The classical assumption test provides certainty that the regression equation in the study has estimation accuracy, is unbiased and consistent (Ghozali, 2014). After the classical assumption test was carried out, multiple linear regression analysis was performed to determine the effect of the work environment, financial rewards, Type A personality on the career choice of a Public Accountant.

\section{RESULTS AND DISCUSSIONS}

\section{Results}

\section{Characteristics of Respondents}

The sample used in this study were accounting students at the FEB Universitas Kristen Satya Wacana, class of 2017 and 2018. Researchers distributed questionnaires online using google form media. Based on the data that has been obtained through the questionnaire collected 182 respondent data. Of these, 179 questionnaires have been filled out completely, and three questionnaires cannot be used because they found incomplete filling out the questionnaire answer sheets. Thus, the questionnaires that have been distributed still meet the number of questionnaires needed to manage the data. Based on the data obtained, an overview of the characteristics of the respondents is presented in Table 2.

Table 2. Characteristics of Respondents

\begin{tabular}{ccc}
\hline Characteristics & Total & Percentage \\
\hline Generation : & 79 & $43 \%$ \\
2017 & 103 & $57 \%$ \\
2018 & & \\
Gender : & 139 & $76 \%$ \\
Woman & 43 & $24 \%$ \\
Man & & $3 \%$ \\
Age : & 5 & $34 \%$ \\
19ears Old & 62 & $46 \%$ \\
20 Years Old & 84 & $14 \%$ \\
21 Years Old & 26 & $3 \%$ \\
22 Years Old & 5 & \\
23 Years Old & & \\
\hline
\end{tabular}

Table 2 shows that the number of respondents in this study consisted of accounting students from the 2017 class of 79 people (43\%) and the 2018 class of 103 people (57\%). Then, of the 182 respondents, 139 female respondents (76\%) and 43 male respondents (24\%). Furthermore, based on age, there are 5 
(3\%) students aged 19 years, 62 people (34\%) students aged 20 years, 84 people (46\%) students aged 21 years, 26 people (14\%) students aged 22 years and $5(3 \%)$ students aged 23 years.

\section{Descriptive Statistics}

Descriptive statistics are used to provide an overview or description of the data in the study. Descriptive statistics are seen from each variable's minimum, maximum, and average scores, as shown in Table 3.

Table 3. Descriptive Statistic Results

\begin{tabular}{lcccc}
\hline & N & Minimum & Maximum & Mean \\
\hline Public accountant career choice & 182 & 9.00 & 36.00 & 27.90 \\
Work environment & 182 & 16.00 & 28.00 & 22.64 \\
Financial rewards & 182 & 13.00 & 24.00 & 18.81 \\
Type A personality & 182 & 12.00 & 20.00 & 16.50 \\
Valid N (list wise) & 182 & & & \\
\hline
\end{tabular}

The descriptive statistics in Table 3 show that the variable for choosing a public accountant career has a minimum score of 9.00. It explains that there are still students who have low interest in choosing a public accountant career. Meanwhile, the maximum score of 36.00 explains that students are very interested in choosing a public accounting career. Then, the average score of 27.90 or 77.50 percent of the maximum score indicates that overall, accounting students are highly interested in choosing a public accounting career. The work environment variable has a minimum score of 16.00. It shows that students can consider the work environment's conditions to have a career as a public accountant. Then, the maximum score of 28.00 explains that there are students who consider the conditions of the work environment in choosing a public accounting career. Furthermore, the average score of 22.64 or 80.85 percent of the maximum score indicates that overall, students are very considerate of the conditions of the work environment in choosing a career as a public accountant.

The financial award variable has a minimum score of 13.00, which explains that students tend to consider financial rewards in choosing a public accounting career. Then, a maximum score of 24 explains that students consider financial rewards in choosing a public accounting career. Then, the average score of 18.81 or 78.37 percent of the maximum score shows that students are very considerate of financial rewards when considering a public accounting career. Type A personality variable has a minimum score of 12.00 . It explains that students tend to have to type Personalities. Then the maximum score of 20.00 explains that there are students who have very high type Personalities. Meanwhile, the average score of 16.50 or 82.50 percent indicates that students have a high Type A personality overall.

\section{Validity and Reliability Test}

Validity testing in this study aims to test whether the indicators used can measure the research variables or not. Testing the validity in this study using a bivariate person. The data is valid if it has a score of $r$ arithmetic $>r$ table that is 0.1216 . Table 4 shows that the calculated $\mathrm{R}$ score for each variable is in the range of $0.200-0.875<\mathrm{R}$ table 0.1216 . So it can be concluded that the research data has met the validity requirements.

Table 4. Validity Test Results

\begin{tabular}{lcc}
\hline \multicolumn{1}{c}{ Variable } & Range of Validity Test Results & Description \\
\hline Work environment & $0.309-0.685$ & Valid \\
Financial Awards & $0.467-0.691$ & Valid \\
Type A Personality & $0.200-0.653$ & Valid \\
Public Accountant Career & $0.612-0.875$ & Valid \\
\hline
\end{tabular}

\section{Reliability Test}

Reliability testing used in this study aims to determine whether the data used is reliable or not. Reliability testing was carried out using Cronbach's alpha method. Data can be said to be reliable if it has Cronbach's alpha score $>0.6$. Table 5 shows that the score of Cronbach's alpha for each variable is in the range of $0.609-0.915>0.6$. It concludes that the research data has met the requirements of reliability. 
Table 5. Reliability Test Results

\begin{tabular}{lcc}
\hline \multicolumn{1}{c}{ Variable } & Reliability Test Results & Description \\
\hline Work environment & 0.678 & Reliable \\
Financial Awards & 0.609 & Reliable \\
Type A Personality & 0.644 & Reliable \\
Public Accountant Career & 0.915 & Reliable \\
\hline
\end{tabular}

\section{Normality Test}

Normality testing in this study aims to determine whether the research data has been normally distributed or not. Testing for normality using the Kolmogorov Smirnov (KS) method. The data can be said to be normal if the KS score is $>0.05$. The results of the normality test show that the KS score is $0.000<0.05$. It indicates that the data in this study are not normally distributed. Furthermore, data reduction was carried out by deleting three data from respondents who had unstandardized scores that were too low, $-17,-10$ and -10. After data reduction, the KS score increased to $0.055>0.05$. So it can be concluded that the data has been distributed normally.

\section{Heteroscedasticity Test}

Heteroscedasticity testing in this study aims to test whether there is an inequality of variance in a regression model from one observation to another. Heteroscedasticity test in this study used the Glejser method. The data is said to meet the criteria for heteroscedasticity if it has a significant score $>0.05$. Table 6 shows that the significance score is $>0.05$, so it can be concluded that there is no heteroscedasticity.

Table 6. Heteroscedasticity Test

\begin{tabular}{lcc}
\hline \multicolumn{1}{c}{ Variable } & Sig & Description \\
\hline Work environment & 0.217 & There is no heteroscedasticity \\
Financial Awards & 0.395 & There is no heteroscedasticity \\
Type A Personality & 0.193 & There is no heteroscedasticity \\
\hline
\end{tabular}

\section{Multicollinearity Test}

The multicollinearity test in this study aims to determine whether the regression model correlates with variables or not. The data is said to be good if there is no correlation between the independent variables. Multicollinearity test uses Tolerance and VIF scores. The data is said to have no multicollinearity if it has a Tolerance score $>0.10$ and a VIF score $<10$. Table 7 shows that each research variable has a Tolerance score $>0.10$ and a VIF score $<10$. So it can be concluded that the research data meet the requirements of multicollinearity.

Table 7. Multicollinearity Test

\begin{tabular}{lccl}
\hline \multicolumn{1}{c}{ Variable } & Tolerance & VIF & Description \\
\hline Work environment & 0.788 & 1.269 & There is no multicollinearity \\
Financial Awards & 0.810 & 1.235 & There is no multicollinearity \\
Type A Personality & 0.959 & 1.043 & There is no multicollinearity \\
\hline
\end{tabular}

\section{Hypothesis Testing}

Hypothesis testing in this study is used to determine whether there is an influence between the independent variables, the work environment, financial rewards, and type A personality on the dependent variable, the choice of a public accountant career. Hypothesis testing is done by using the significance score and the score of $\mathrm{T}$ table. The independent variable can affect the dependent variable if it has a significant score less than 0.05 and the calculated $\mathrm{T}$ score is greater than the T table.

Table 8. Hypothesis Testing

\begin{tabular}{|c|c|c|c|}
\hline Variable & $\mathbf{t}$ & Sig. & Conclusion \\
\hline Work environment & 4.622 & 0.000 & Positive influence \\
\hline Financial Awards & -0.499 & 0.618 & No effect \\
\hline Type A Personality & 2.141 & 0.034 & Positive influence \\
\hline
\end{tabular}


Table 8 shows that the influence of the work environment on the choice of a public accountant career has a significant score of $0.000<0.05$ and a calculated $\mathrm{T}$ score of $4.622>\mathrm{T}$ table 0.67586 . It concludes that the work environment variable has a positive and significant effect on the choice of a public accountant career. The effect of financial rewards on the choice of a public accounting career has a significant score of $0.618>0.05$ and a calculated $T$ score of $-0.499<\mathrm{T}$ table of 0.67586 . So it can be concluded that the financial award variable does not influence the choice of a public accountant career. The influence of type A personality on the choice of a public accountant career has a significant score of $0.034<0.05$. Meanwhile, the calculated $\mathrm{T}$ score is $2.141>\mathrm{T}$ table is 0.67586 . It concludes that the influence of personality has a positive and significant influence on the choice of a public accounting career.

\section{Discussion \\ Influence of Work Environment (X1) on Public Accountant Career Choice (Y)}

The results of testing the first hypothesis show that the work environment has a positive effect on the choice of a public accountant career, seen from a significant score of $0.000<0.05$ and a calculated T score of 4.622> T table 0.67586. Thus the first hypothesis in this study is accepted. The work environment has an important role in choosing a career. A better work environment can increase student interest in a career as a public accountant. The results of this study support the research that the work environment positively affects the choice of a public accountant career (Puspitaningsih, 2017; Wicaksono \& Aisyah, 2017). The better the work environment provided, the student's interest in a career as a public accountant will increase. A good work environment is when a public accountant can carry out all his duties optimally and on time. Therefore, the work environment becomes a consideration for students to choose a career. The work environment greatly influences students' interest in choosing a public accounting career (Febriyanti, 2019). The work environment is all aspects that workers will face in carrying out all their duties and responsibilities, which are expected to provide a comfortable situation.

\section{Effect of Financial Award (X2) on Public Accountant Career Selection (Y)}

The results of testing the second hypothesis indicate that financial rewards do not affect the choice of a public accountant career with a significant score of $0.618>0.05$ and a calculated $\mathrm{T}$ score of $-0.499<\mathrm{T}$ table of 0.67586 . Thus the second hypothesis in this study was rejected. There are several respondents' answers who do not agree with the statement regarding the high starting salary. It may cause fresh graduate students to want to have a variety of work experience first and want to develop themselves first so that they do not consider the amount of salary they will receive while working. The results of this study show the same results as the research which shows that financial rewards do not affect the choice of a public accountant career (Dary \& Ilyas, 2019). It shows that students do not consider financial rewards first but prefer to get various work experience. However, in contrast to the research states that financial rewards positively affect the choice of a public accountant career (Rahayu \& Putra, 2019; Wicaksono \& Aisyah, 2017). It is probably due to the higher the financial rewards are given, the student's interest in a career as a public accountant will also increase.

\section{Influence of Type A Personality (X3) on Public Accountant Career Selection (Y)}

The results of testing the third hypothesis indicate that type A personality has a positive effect on the choice of a public accountant career seen from a significant score of $0.034<0.05$. Meanwhile, the calculated T score is $2.141>\mathrm{T}$ table is 0.67586 . Students who have a type A personality tend to choose a public accounting career because they feel it fits their personality and work. Students who choose to become public accountants feel that their career must be by their personality or characteristics. In the future, there is no conflict between their work and personality. Because one of the factors a person loses his job because it is not by the personality possessed by the field of work. The results of this study are different from the research which states that personality type does not affect the choice of a public accountant career (Wicaksono \& Aisyah, 2017). There are students with type B personality who show interest in a career as a public accountant, so there is no difference in views about personality types A and B in choosing a career as a public accountant.

\section{CONCLUSION}

Based on the research that has been done, the following conclusions are obtained. First, the work environment has a positive effect on the choice of a public accountant career. The better the work environment provided, the higher the student's interest in a career as a public accountant. Second, financial rewards do not influence the choice of a public accountant career. Students prefer to have various experiences first, so they do not consider the number of financial rewards obtained. Third, type A personality has a positive effect on the choice of a public accountant career. Students with type A 
personalities choose a career as a public accountant because they feel suitable or by their personality. There are several limitations in this study. First, the study only looked at one perception of universities. Second, there are still some respondents who do not take the questionnaire seriously. Third, when filling out the questionnaire, respondents were not accompanied. There might be respondents who did not understand the meaning of the questionnaire statements, so they filled out the questionnaire carelessly.

\section{REFERENCES}

Asri, A., Amin, M., \& Mawardi, M. C. (2020). Pengaruh Persepsi Mahasiswa Akuntansi Mengenai Lingkungan Kerja Akuntan Publik dan Etika Profesi Akuntan Publik (Studi Kasus Pada Mahasiswa Akuntansi UNISMA,UNM dan UM). Jurnal Ilmiah Riset Akuntansi, 9(9), 47-57. http://www.riset.unisma.ac.id/index.php/jra/article/view/8510.

Chan, A. S. (2012). Analisis Faktor-Faktor Mempengaruhi Mahasiswa Akuntansi Dalam Pemilihan Karir Menjadi Akuntan Publik. Jurnal Ilmiah Mahasiswa Akuntansi, 1(1), 53-58. http://jurnal.wima.ac.id/index.php/JIMA/article/view/13.

Coman, C., Țîru, L. G., Meseșan-Schmitz, L., Stanciu, C., \& Bularca, M. C. (2020). Online teaching and learning in higher education during the coronavirus pandemic: Students' perspective. Sustainability (Switzerland), 12(24), 1-22. https://doi.org/10.3390/su122410367.

Dary, A. W., \& Ilyas, F. (2019). Pengaruh Gender, Penghargaan Finansial Dan Pertimbangan Pasar Kerja Terhadap Minat Mahasiswa Akuntansi Untuk Berkarir Menjadi Akuntan Publik Dan Non Akuntan Publik. Jurnal Akuntansi, 7(1), 51-60. https://doi.org/10.33369/j.akuntansi.7.1.51-60.

Fauziah, F. (2020). Pengantar Dasar Akuntansi Buku 1: Teknik dan Konsep Penyusunan Laporan Keuangan. Muhammadiyah University Press.

Febriyanti, F. (2019). Faktor-Faktor Yang Mempengaruhi Minat Mahasiswa Akuntansi Dalam Pemilihan Karir Sebagai Akuntan Publik. Jurnal Akuntansi: Kajian Ilmiah Akuntansi (JAK), 6(1), 88. https://doi.org/10.30656/jak.v6i1.1036.

Ghozali, I. (2014). Ekonometrika: Teori, Konsep dan Aplikasi dengan IBM SPSS 22. Badan Penerbit Undip.

Iswati, S. (2017). Pengaruh Komitmen Profesional, Tipe Kepribadian, Gender Terhadap Kepuasan Kerja Akuntan Publik. EKUITAS Jurnal Ekonomi Dan Keuangan), 12(1), 37. https://doi.org/10.24034/j25485024.y2008.v12.i1.2058.

Laksmi, A. C., \& Al Hafis, S. I. (2019). The influence of accounting students' perception of public accounting profession: A study from Indonesia. Journal of Contemporary Accounting, 1(1), 47-63. https://doi.org/10.20885/jca.vol1.iss1.art5.

Lukman, H., \& Juniati, C. (2017). Faktor Yang Pengaruhi Pemilihan Karir Sebagai Akuntan Publik Bagi Mahasiswa Pts Wasta Dengan Pendekatan Reasoned Action Model. Jurnal Akuntansi, 20(2), 202. https://doi.org/10.24912/ja.v20i2.54.

Matthews, K. A. (1982). Psychological perspectives on the type A behavior pattern. Psychological Bulletin, 91(2), 293. https://psycnet.apa.org/record/1988-04851-001.

Merdekawati, D., \& Sulistyawati, A. (2011). Faktor-Faktor yang Mempengaruhi Pemilihan Karir Akuntan Publik dan Non Akuntan Publik. Jurnal IImu Ekonomi ASET, 13(1), 9-19. https://widyamanggala.ac.id/journal/index.php/jurnalaset/article/view/69.

Mulyadi. (2012). Auditing (6th ed.). Penerbit Salemba Empat.

Murdiawati, D. (2020). Faktor-Faktor Yang Mempengaruhi Minat Mahasiswa Akuntansi Di Surabaya Untuk Memilih Karir Menjadi Akuntan Publik. Jurnal Akuntansi Dan Pajak, 20(2), 248-256. https://core.ac.uk/download/pdf/287298836.pdf.

Puspitaningsih, D. (2017). Analisis Faktor-Faktor Yang Mempengaruhi Pemilihan Karir Sebagai Akuntan Publik (Studi Kasus Pada Mahasiswa Akuntansi Universitas PGRI Yogyakarta). Universitas PGRI Yogyakarta.

Rahayu, P. N., \& Putra, N. W. A. (2019). Pengaruh Motivasi, Penghargaan Finansial, Pelatihan Profesional, Pertimbangan Pasar Kerja, Lingkungan Pada Karir Akuntan Publik. E-Jurnal Akuntansi, 28(2), 1200. https://doi.org/10.24843/eja.2019.v28.i02.p16.

Ramdani, R. F., \& Zulaikha, Z. (2014). Analisis Faktor-Faktor yang Mempengaruhi Pemilihan Kariri Mahasiswa Akuntansi (Studi Empiris Mahasiswa Akuntansi di Perguruan Tinggi di Semarang ). $\begin{array}{llll}\text { Diponegoro Journal of } & \text { Accounting, }\end{array}$ https://ejournal3.undip.ac.id/index.php/accounting/article/view/6027.

Sari, P. S. M. (2019). Pengaruh Tipe Kepribadian A dan B Pada Kinerja Mahasiswa Akuntansi. E-Jurnal Akuntansi, 29(1), 50-63.

Sugiyono. (2014). Metode Penelitian Pendidikan Pendekatan Kuantitatif, Kualitatif, dan R\&D. Alfabeta.

Suharti, S., \& Irman, A. P. (2020). Analisi Faktor-Faktor Yang Mempengaruhi Pemilihan Karir Sebagai 
Akuntan Publik (Studi Empiris pada Mahasiswa Akuntansi Perguruan Tinggi Pelita Indonesia Di Kota Pekanbaru). Kurs: Jurnal Akuntansi, Kewirausahaan Dan Bisnis, 5(1), 85-101. http://www.ejournal.pelitaindonesia.ac.id/ojs32/index.php/KURS/article/view/731.

Susil, A., Rumende, C. M., Pitoyo, C. W., Santoso, W. D., Yulianti, M., Herikurniawan, Sinto, R., Singh, G., Nainggolan, L., Nelwan, E. J., Chen, L. K., Widhani, A., Wijaya, E., Wicaksana, B., Maksum, M., Annisa, F., Jasirwan, C. O., \& Yunihastuti, E. (2020). Coronavirus Disease 2019: Tinjauan Literatur Terkini. $\begin{array}{lllll}\text { Jurnal Penyakit Dalam } & \text { Indonesia, }\end{array}$ https://doi.org/http://dx.doi.org/10.7454/jpdi.v7i1.415.

Suyono, N. A. (2014). Analisis Faktor-Faktor Yang Mempengaruhi Pemilihan Karir Sebagai Akuntan Publik (Studi Empiris Pada Mahasiswa Akuntansi Unsiq). Jurnal Penelitian Dan Pengabdian Kepada Masyarakat UNSIQ, 1(2), 69-83. https://ojs.unsiq.ac.id/index.php/ppkm/article/view/235.

Wicaksono, Y., \& Aisyah, M. N. (2017). Pengaruh Finansial, Lingkungan Kerja dan Tipe Kepribadian Untuk Berkarier menjadi Akuntan Publik. Jurnal Profita: Kajian Ilmu Akuntansi, 6(3), 1-19. https://core.ac.uk/download/pdf/185259640.pdf.

Yendrawati, R. (2017). Persepsi Mahasiswa Akuntansi Mengenai Faktor-Faktor Yang Mempengaruhi Pemilihan Karir Sebagai Akuntan. Jurnal Fenomena, 5(2), 1-11. https://doi.org/10.32897/sikap.v1i2.55. 